\title{
Identification and characterization of Hibiscus latent Fort Pierce virus in Italy
}

\author{
Luca Nerva $^{1} \cdot$ Marta Vallino $^{1} \cdot$ Massimo Turina $^{1} \cdot$ Marina Ciuffo $^{1}$ \\ Received: 16 January 2018 / Accepted: 6 March 2018 / Published online: 19 March 2018 \\ (C) Società Italiana di Patologia Vegetale (S.I.Pa.V.) 2018
}

Hibiscus plants are common ornamentals in subtropical areas and are vegetatively propagated for distribution in many geographic areas. Hibiscus latent Fort Pierce virus (HLFPV) from the genus Tobamovirus in the family Virgaviridae was described for the first time in Fort Pierce, Florida, USA, on Hibiscus rosa-sinesis plants showing diffuse chlorotic spots, ringspots and chlorotic mottle (Adkins et al. 2006). HLFPV was also reported in Japan, Brazil, Indonesia and Thailand (Gao et al. 2016). An hibiscus plant with typical HLFPV symptoms was identified in a nursery in Liguria region (Italy) in 2016. Crude leaf extract was inoculated on a range of test plant species. Virus-like symptoms were present on Chenopodium quinoa (local lesion), Nicotiana benthamiana and $N$. occidentalis (locally and systemically). Total RNA was extracted from locally infected C. quinoa and sequenced with an Illumina HiSeq 2000 apparatus. The 6431 nt sequence (assembled from 811570 reads, with average coverage of 18400) was compared to the sequence of other HLFPV isolates in GenBank using BLAST 2.6.0. The Italian HLFPV isolate Hib2IT (GenBank accession number KY769775) had more than $99 \%$ identity with other HLFPV isolates. The presence of HLFPV-Hib2IT in the original host and inoculated herbaceous host was confirmed by RT-PCR using HLFPV$\mathrm{CP}$ specific primers designed in the HLFP coat protein (CP) gene to amplify a $330 \mathrm{bp}$ fragment (Hib2_CP400F 5'AGATCTAACAGCTTTCAGACGCA-3'; Hib2_CP400R 5'-TGATTGTACACGGCGGATCC-3'). Sequence comparison between the CP gene of HLFPV-Hib2IT and HLFPV isolate $\mathrm{J}$ (GenBank accession number NC_025381.1) revealed four nucleotide changes which lead to two amino acid changes (nt position 5959, Ile to Thr and 5991, Asp to Asn). Unexpectedly, no rod-shaped particles were observed by electron microscopy in spite of numerous attempts. More work is needed to determine whether the amino acid changes could result in CP sub-units deficient in virus particle assembly. To our knowledge, this is the first report of HLFPV in Italy.

Acknowledgments We thank Riccardo Lenzi, Caterina Perrone and Elena Zocca for excellent technical assistance.

\section{Compliance with ethical standards}

Conflict of interest The authors declare that they have no conflict of interest.

Human and animal rights This article does not contain any studies with human participants or animals performed by any of the authors.

\section{References}

Adkins S, Kamenova I, Chiemsombat P, Baker C, Lewandowski D (2006) Tobamoviruses from hibiscus in Florida and beyond. Acta Hortic 277:65-70

Gao R, Niu S, Dai W, Kitajima E, Wong SM (2016) Hibiscus latent Fort Pierce virus in Brazil and synthesis of its biologically active fulllength cDNA clone. Virus Genes 52:754-757
Marina Ciuffo

marina.ciuffo@ipsp.cnr.it

1 Institute for Sustainable Plant Protection, CNR, Strada delle Cacce 73, 10135 Torino, Italy 